\title{
Synthesis of Acridin-2-yl(Phenyl)Methanone via Palladium Catalyzed Carboannulation of Internal Acetylene and Its Antibacterial and Antibiofilms Activity
}

\begin{abstract}
A. LABENA ${ }^{1}$, N. E. A. ABD EL-SATTAR ${ }^{2}$, A. HAMMED², S. RAMDAN², A. M. ZIDAN², A. MOHAMMED ${ }^{3}$, O. A. ALGHAMDI $^{3}$ and A. M. ELAZZAZY3,4

${ }^{1}$ Egyptian Petroleum Research Institute (EPRI), Processes development department, Biotechnology laboratory, Nasr City, Cairo, Egypt. ${ }^{2}$ Organometallic Synthesis Lab., Department of Chemistry, Faculty of Science, Ain Shams University, Abbassia, Cairo, Egypt. ${ }^{3}$ Department of Biology, college of Science, University of Jeddah, Jeddah, Saudi Arabia. ${ }^{4}$ Department of Chemistry of Natural and Microbial Products, Division of Pharmaceutical and Drug Industries, National Research Centre, Giza, Egypt
\end{abstract}

Labena et al.: Synthesis and Antibacterial Activity of acridin-2-yl(phenyl)methanone

\begin{abstract}
Many substituted acridin-2-yl(phenyl) methanones have been successfully prepared in good yields by reacting functionally substituted aryl halides with many internal acetylenes in presence of a palladium catalyst $\mathrm{Pd}(\mathrm{dba}) 2$. The end product of this reaction has also been synthesized via reaction of cis- and trans3-(2-chloro-6-methoxyquinolin-3-yl)-1-(3,4,5-trimethoxyphenyl)prop-2-en-1-one palladium complexes towards acetylene in an aqueous medium. This reaction was believed to proceed via region-selective arylpalladation of the acetylene and subsequent nucleophilic displacement of the palladium, which further produced vinylpalladium intermediates. The intermediates and the final products have been tested for broad-spectrum antibacterial and antibiofilm activities.
\end{abstract}

Key words: Acridinpalladium complexes, cyclopalladated, acetylene, acridin-2-yl(phenyl)methanone, antibacterial activity, antibiofilm activity

Aqueous-organic two-phase organometallic catalysis plays a crucial role in the green chemical technology development (fig. 1). Water is considered as an environmentally friendly solvent. In order to separate the catalyst from the hydrophobic products, it should be rendered water-soluble via its ligands. The meta-carbon bond in ortho-palladated aromatic compound undergoes insertion reaction with carbon monoxide, alkenes, acyl halides and alkynes and after decomposition yields attractive organic products ${ }^{[1-7]}$. Organo-palladium compoundsarecommonlyused inmany organicreactions such as ortho-metallated arylpalladium complexes and alkynes that afford a special interest ${ }^{[5,8,9]}$. Nevertheless, neither the ortho-metallation of aromatic aldehydes nor the synthesis of ortho-formyl arylpalladium complexes has been reported in a preliminary communication ${ }^{[10]}$. It has been reported that the quinoline ring systems are essential structural units in naturally occurring alkaloids and synthetic compounds with attractive biological activities ${ }^{[11]}$. Moreover, It has been reported that acridine derivatives as a class of compounds that are being effectively applied as anticancer drugs regardless of their high cytotoxic activity ${ }^{[12]}$. Furthermore, the development of new annulation processes, the most efficient and economical reactions of creating cyclic molecules, is considered as one of the most impressive and crucial steps in the synthesis of organic compounds ${ }^{[13]}$. In addition, coupling two or more independent acyclic moieties to compose several bonds in one direct process leads to the rapid synthesis of complex molecules without spending time and chemicals in the separation of intermediate-products and their reintroduction into consequent steps. Palladium, transition metals, is particularly advantageous in the

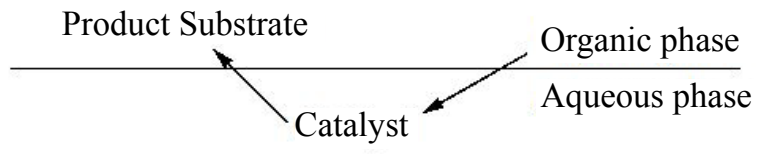

Aqueous-organic two-phase catalysis

Fig. 1: Aqueous-organic two-phase-catalysis 
synthesis of organic compounds as it imposes the most accomplished possibilities for carbon-carbon bond formation ${ }^{[14,15]}$. Palladium reagents have been applied abundantly to synthesis numerous heterocyclic compounds via cyclic carbopalladation and annulation reactions ${ }^{[16]}$. It has been previously reported that substrates bearing a ketone group can easily mediate palladium processes, which further leads to products with remains intact ketonic group ${ }^{[17]}$. At this time, the full details of internal carboannulation of alkynes and bicyclic alkenes by 2-iodobenzonitrile (1), which induce 2,3-diarylindenones (3) and related polycyclic aromatic ketones have been outlined. With regard to previous reports on the alkyne annulation process, the mechanism of the formation of 2,3-diarylindenones (3) from 2-iodobenzonitrile (1) and diphenylacetylene (2) was proposed $^{[18]}$. Furthermore, the oxidative addition of 2-iodobenzonitrile (1) to $\operatorname{Pd}(0)$, leads to the formation of $\mathrm{Pd}(\mathrm{II})$, which preceded diphenylacetylene (2) insertion afterward produces vinyl palladium intermediate. The latter adds up across the carbon-nitrogen triple bond of the neighbouring cyano-group to have an intermediate, which further hydrolyses to the indenone $(3)^{[19]}$. The reduction of the intermediate $\mathrm{Pd}(\mathrm{II})$ species is needed and important to afford a catalytic reaction that takes place at some steps in the reaction.

In this work, the development of an oxidative addition reaction and an annulation reaction in an aqueous medium has been disclosed, which further described the first preparation of some acridin-2-yl(phenyl) methanone $7 \mathrm{a}, \mathrm{b}$ at room temperature as a new method. Recently, there is a lot of growing interest in the synthesis and evaluation of the biological and pharmaceutical activities of the new organometallic complexes ${ }^{[20-22]}$. The role of metal ions in the structure and biological action is essential. However, the mechanistic action at a molecular level is not well understood ${ }^{[23,24]}$. The hypothesized antibacterial mechanism of organometallic complexes such as palladium complex compounds can be mainly attributed to their ability to inhibit the metabolic pathway, which alters the DNA replication. Furthermore, such compounds have a strong ability to form hydrogen bonding with the constituents of cell mainly the cell wall ${ }^{[20]}$. The application of palladium complex compounds was directed not only for inhibiting the microorganism present in bulk phase (planktonic) but also for the microorganisms that attached to biotic and abiotic surfaces (biofilms). Biofilms are layers of one multi-species microbial community, extracellular polymeric substances (EPS), inorganic material and water ${ }^{[25]}$. Biofilm, the highly constructed microbial communities, has huge negative impact on human health, environment and industries ${ }^{[26]}$. In this regard, nowadays, scientists are looking for an effective method to prevent biofilm development on different surfaces by inhibiting/reduce the initial microbial attachment ${ }^{[27]}$. Therefore, the aim of the present work was directed to evaluate the antibacterial and antibiofilm activity of the synthesized vinylpalladium intermediates in comparison to the final reaction product.

\section{MATERIAL AND METHODS}

All chemicals were purchased from Sigma-Aldrich and all melting points were uncorrected. Nuclear magnetic resonance (NMR)-spectra and high-resolution mass (HRMS)-mass spectra were recorded using a Brucker-300 MHz spectrometer and Brucker FT-MS, respectively. Dichloromethane was distilled over calcium hydride. In addition, Thin layer chromatography (TLC) was accomplished using commercially prepared 60-mesh silica gel plates. All reagents in this study were obtained commercially unless otherwise stated. All reactions were performed under nitrogen atmosphere in well-dried glassware.

\section{Synthesis of 3-(2-chloroquinolin-3-yl)-1-arylprop-2- en-1-one derivatives:}

3-(2-chloro-6-methoxyquinolin-3-yl)-1-(3,4,5trimethoxyphenyl)prop-2-en-1-one (6) were prepared by the reaction of 2-chloroquinoline-3-carboxaldehyde derivative (4) with acetophenone derivative (5) $)^{[28]}$.

\section{Synthesis of trans-chloro[3-(6-methoxyquinolin- 3-yl)-1-(3,4,5-trimethoxyphenyl)prop-2-en-1-one] bis(triphenylarsine) palladium(II) (7):}

A mixture of $\left[\mathrm{Pd}(\mathrm{dba})_{2}\right](432 \mathrm{mg}, 0.75 \mathrm{mmol})$, triphenyl arsine (459.3 mg, $1.5 \mathrm{mmol})$ and ketone $(6)(0.75 \mathrm{mmol})$ was mixed under $\mathrm{N}_{2}$ in dry acetone $(30 \mathrm{ml})$. The reaction mixture was stirred for $3-5 \mathrm{~h}$ at room temperature, concentrated and $\mathrm{CH}_{2} \mathrm{Cl}_{2}(25 \mathrm{ml})$ was added. The solution was further passed through a pad of silica gel- $\mathrm{MgSO}_{4}$ (3:1) in a fritted funnel, and then evaporated under reduced pressure to dryness and washed with $\mathrm{Et}_{2} \mathrm{O}$. The product was filtered affording pale brown solid (348 $\mathrm{mg}, 41 \% \mathrm{w} / \mathrm{w}$ yield). TLC (ethanol:petroleum ether, $1: 1), \mathrm{R}_{\mathrm{f}}=0.739$; mp: 164-166 ${ }^{\circ}$; Analytically calculated value for $\mathrm{C}_{59} \mathrm{H}_{53} \mathrm{As}_{2} \mathrm{ClNO}_{5} \mathrm{Pd}$ (1147.77) is $\mathrm{C} 61.74 \%$, H $4.65 \%$, N $1.22 \%$. Found C $65.96 \%$, H $4.67 \%$, N 1.03 \%. IR (v, $\left.\mathrm{cm}^{-1}\right): 1655(\mathrm{C}=\mathrm{O}), 1618(\mathrm{C}=\mathrm{N}, \mathrm{C}=\mathrm{C}), 1580$, 1233 (C-O), 1125, 2923 (C-H aliphatic), 2986 (=C-H) and $3050\left(\mathrm{C}-\mathrm{H}\right.$ aromatic) $\mathrm{cm}^{-1}$. 1H-NMR $(300 \mathrm{MHz}$, $\left.\mathrm{CDCl}_{3}\right): \delta 8.19-8.14(\mathrm{~d}, 1 \mathrm{H}, 1,3 \mathrm{JHH}=15.6 \mathrm{~Hz},=\mathrm{CH}-$ 
$\mathrm{CO})$, 7.13-7.08 (d, 1H, 1,3JHH=15.9 Hz, Ar-CH=), $3.97\left(\mathrm{~s}, 6 \mathrm{H}, \mathrm{m}-\mathrm{OCH}_{3}\right), 3.92\left(\mathrm{~s}, 3 \mathrm{H}\right.$, Quinoline- $\left.\mathrm{OCH}_{3}\right)$, $3.61\left(\mathrm{~s}, 3 \mathrm{H}, \mathrm{p}-\mathrm{OCH}_{3}\right), 8.39\left(\mathrm{~s}, 1 \mathrm{H}\right.$, Quinoline- $\left.\mathrm{H}_{4}\right), 7.96-$ $7.93(\mathrm{~d}, 1 \mathrm{H}, 1,3 \mathrm{JHH}=9.3 \mathrm{~Hz}$, Quinoline-H8), 7.78 (s, 1H, Quinoline- $\left.\mathrm{H}_{5}\right)$ and 7.73-7.32 (m, 33H, Ar-H).

Synthesis of cis-chloro[3-(6-methoxyquinolin-3yl)-1-(3,4,5-trimethoxy phenyl)prop-2-en-1-one] (1,10-phenanthrene)palladium(II) (8):

A mixture of $\left[\mathrm{Pd}(\mathrm{dba})_{2}\right]$ (432 $\left.\mathrm{mg}, 0.75 \mathrm{mmol}\right)$, 1,10-phenanthrene (135 $\mathrm{mg}, 0.75 \mathrm{mmol})$ and ketone (6) $(0.75 \mathrm{mmol})$ was mixed under $\mathrm{N}_{2}$ in dry acetone $(30 \mathrm{ml})$. The reaction mixture was stirred for 3-5 $\mathrm{h}$ at room temperature, then was concentrated and $\mathrm{CH}_{2} \mathrm{Cl}_{2}$ (25 ml) was added. The solution was then passed through a pad of silica gel- $\mathrm{MgSO}_{4}$ (3:1) in a fritted funnel, and then evaporated under reduced pressure to dryness and washed with $\mathrm{Et}_{2} \mathrm{O}$. The product was filtered to gives a green solid (248 mg, $47 \% \mathrm{w} / \mathrm{w}$ yield). TLC (ethanol:petroleum ether, $1: 1$ ), $\mathrm{R}_{\mathrm{f}}=0.708 ; \mathrm{mp}$ : 184-188 ; Anal. Calc. for $\mathrm{C}_{34} \mathrm{H}_{28} \mathrm{ClN}_{3} \mathrm{O}_{5} \mathrm{Pd}^{\circ} \mathrm{CH}_{2} \mathrm{Cl}_{2}$ (700.48) is C $53.52 \%$, H $3.85 \%$, N $5.35 \%$. Found C $55.84 \%, \mathrm{H} 4.08 \%$, N $4.57 \%$. IR $\left(\mathrm{v}, \mathrm{cm}^{-1}\right): 1663(\mathrm{C}=\mathrm{O})$, $1616(\mathrm{C}=\mathrm{N}, \mathrm{C}=\mathrm{C}), 1580,1233(\mathrm{C}-\mathrm{O}), 1125,2940(\mathrm{C}-\mathrm{H}$ aliphatic), $3016(=\mathrm{C}-\mathrm{H})$ and $3052(\mathrm{C}-\mathrm{H}$ aromatic) $\mathrm{cm}^{-1}$. 1H-NMR (300 MHz, DMSO): $\delta$ 8.04-7.99 $(\mathrm{d}, 1 \mathrm{H}, 1,3 \mathrm{JHH}=15.6 \mathrm{~Hz},=\mathrm{CH}-\mathrm{CO}), 7.49-7.43(\mathrm{~d}, 1 \mathrm{H}$, $1,3 \mathrm{JHH}=15.5 \mathrm{~Hz}, \mathrm{Ar}-\mathrm{CH}=), 3.93(\mathrm{~s}, 12 \mathrm{H}, \mathrm{OCH} 3)$, 9.06 (s, 1H, Quinoline-H4), 8.97-8.94 (d, 1H, 1,3JHH $=8.4 \mathrm{~Hz}$, Quinoline-H8) and 8.74-7.42 (m, 12H, Ar-H).

\section{General procedure for the reaction of trans/cis-} palladium complexes with acetylene:

Acetylene was bubbled for $5 \mathrm{~min}$ through a solution of complex (100 mmol) in $\mathrm{CH}_{2} \mathrm{C}_{12}(15 \mathrm{ml})$ and few drops of water were added. The reaction mixture was stirred for $24 \mathrm{~h}$ under the acetylene atmosphere. Decomposition to metallic palladium was noticed. The suspension was further filtered and the filtrate was then evaporated under reduced pressure to dryness and $\mathrm{Et}_{2} \mathrm{O}(10 \mathrm{ml})$ was added. The resulting suspension was filtered and the filtrate was evaporated again under reduced-pressure to dryness and n-hexane $(10 \mathrm{ml})$ was added. The resulting suspension was filtered to give the following reaction:

\section{Reaction of trans-palladium complexes with acetylene:}

Reaction of trans-chloro[3-(6-methoxyquinolin3-yl)-1-(3,4,5-trimethoxyphenyl)prop-2-en-1-one] bis(triphenylarsine)palladium(II) (7) afforded pale brown solid (24 mg, $75 \% \mathrm{w} / \mathrm{w}$ yield); mp: 202-204\%
IR $\left(v, \mathrm{~cm}^{-1}\right): 1662(\mathrm{C}=\mathrm{O}), 1617(\mathrm{C}=\mathrm{N}, \mathrm{C}=\mathrm{C}), 1580$, 1234 (C-O), 1125, 2939 (C-H aliphatic) and 3051 (C-H aromatic) $\mathrm{cm}^{-1}$. 1H-NMR (300 MHz, CDCl3): $\delta 3.97$ $(\mathrm{s}, 12 \mathrm{H}, \mathrm{OCH} 3), 8.38(\mathrm{~s}, 1 \mathrm{H}$, acridine-H9) and 8.18-7.15 (m, 8H, Ar-H). MS, $m / z(\%): 404(\mathrm{M}+1)$, 378 (100), 210 (10), 168 (42), 152 (16), 91 (3), 77 (5), $50(11)$.

\section{Reaction of cis-palladium complexes with acetylene:}

Reaction of cis-chloro[3-(6-methoxyquinolin3-yl)-1-(3,4,5-trimethoxyphenyl)prop-2-en-1-one] (1,10-phenanthrene)palladium(II) (8) afforded a pale brown solid (17 mg, $33 \% \mathrm{w} / \mathrm{w}$ yield), mp: 202-204. IR (v, cm $\left.{ }^{-1}\right): 1659(\mathrm{C}=\mathrm{O}), 1616(\mathrm{C}=\mathrm{N}, \mathrm{C}=\mathrm{C}), 1590$, 1245 (C-O), 1128, 2940 (C-H aliphatic) and 3050 (C-H aromatic) $\mathrm{cm}^{-1}$. 1H-NMR (300 $\left.\mathrm{MHz}, \mathrm{CDCl}_{3}\right): \delta 3.97$ $\left(\mathrm{s}, 12 \mathrm{H}, \mathrm{OCH}_{3}\right), 8.40(\mathrm{~s}, 1 \mathrm{H}$, acridine-H9) and 8.20-7.18 (m, 8H, Ar-H).

\section{Evaluation of the reaction intermediates and final compounds as antimicrobial agents:}

The following strains Staphylococcus aureus (DSMZ 3463), Bacillus subtilis (ATCC 6633), Escherichia coli (ATCC 8739) and Pseudomonas aeruginosa (ATCC 9027) were used in this study.

The antibacterial activity of the produced vinylpalladium intermediates $(7,8)$ that represented trans and cispalladium complexe intermediate compounds, respectively and the final product (9) were determined using a modified agar well diffusion method ${ }^{[29]}$. The tested bacterial strains were streaked on the nutrientagar plates. A sterile $10 \mathrm{~mm}$ borer was applied to make wells and $0.1 \mathrm{ml}$ of the reaction-products $(7,8,9)$ were introduced into each well. Furthermore, the plates were incubated overnight at a temperature of $37^{\circ}$. Afterward, the antibacterial activities the reaction-products $(7,8,9)$ were evaluated by measuring the inhibition zone diameter $(\mathrm{mm})$ in 3 different fixed directions. The average values of the 3 measurements were reported. The negative control (sterile water) and the positive controls (tetracycline $30 \mu \mathrm{g}$ and nalidixic acid $30 \mu \mathrm{g}$ ) were used.

Minimum inhibitory concentrations (MICs) and minimum bactericidal concentrations (MBCs):

MIC and MBC values of the reaction-products $(7,8,9)$ were estimated using a two-fold microdilution method in 96-well flat-bottomed microtiter plates ${ }^{[31,32]}$. The tested bacterial strains were cultivated in a trypticase soy broth (TSB, Difco Co; Becton Dickinson, Sparks, 
MD). The inoculum was prepared as previously reported by Labena et al. and according to McFarland standard $0.5^{[33,34]}$. The reaction-products $(100 \mu 1,7,8,9)$ were serially diluted using TSB onto the microtiter plates and further inoculated with a $100 \mu 1$ of the microbial suspension to achieve a final volume of $200 \mu 1$ parallel with one positive (inoculated without the reaction products) and negative control (only media without the reaction products) wells. The plates were incubated under aerobic condition at $37^{\circ}$ for $20-22 \mathrm{~h}$. This test was performed 3 times. The MICs were defined as the lowest concentration of the reaction products $(7,8,9)$ that inhibited the development of visible bacterial growth on TSB after the incubation period. A sample of $10 \mu \mathrm{l}$ was taken from wells that showed no visible growth and further sub-cultured onto TSB plates ${ }^{[35]}$. The plates were incubated for $20-22 \mathrm{~h}$ at $37^{\circ}$ until microbial growth can be observed in the positive control plate. The MBCs were evaluated by determining the lowest concentrations of the reaction products $(7,8,9)$ that inhibited the visible bacterial growth on TB plates after the incubation period. All tests were performed three times.

\section{Antibacterial biofilms and minimum biofilm inhibition concentration (MBIC):}

The protocol of antibacterial biofilms activity was estimated by a semi-quantitative adherence assay on 96-well tissue culture plates NunclonTM (use F, PS, not tissue-culture treated, Nunc GmbH \& Co., Wiesbaden, Germany) ${ }^{[36,37]}$. The bacterial innocula of this experiment has been prepared as previously reported in the McFarland turbidity 0.5 method $^{[34]}$. A sample of $100 \mu 1$ of the reaction products $(7,8,9)$ were serially diluted using TSB (supplemented with $1 \%$ glucose) onto the microtiter plates and further inoculated with a $100 \mu \mathrm{l}$ of the microbial suspension to achieve a final volume of $200 \mu 1$ parallel with one positive and negative control wells. Afterward, the plates were incubated for 20-22 $\mathrm{h}$ at $37^{\circ}$. After incubation, the cell suspension was discarded. The plates were then washed with $200 \mu 1$ of $\mathrm{pH} 7.4$ phosphate buffered saline (PBS) for 3 times in order to remove non-adherent cells. Afterwards, the plates were dried in an inverted position at $65^{\circ}$ for $1 \mathrm{~h}$. The plates were fixed with $200 \mu \mathrm{l}$ of $97 \%$ ethanol and stained with $200 \mu \mathrm{l}$ of $1 \%$ (w/v) crystal violet (Merck, Germany) for 5 min. The rest of the stain was rinsed off using tap water and then dried for $2 \mathrm{~h}$. The attached cells have appeared as purple rings formed on the bottoms and sides of the wells ${ }^{[38]}$. The experiment was performed in triplicates. The MBIC is defined as the lowest concentration of the antibiofilm agent that inhibited the development of visible microbial growth adherence (biofilm) on TSB after an incubation period.

To confirm the antibiofilm activity of the reaction products $(7,8,9)$ at MIBC against bacterial biofilms, scanning electron microscopy (Model Quanta 250 Field Emission Gun at magnification ranging from 14X up to 1000000 and resolution for Gun 1n and operated at an acceleration voltage of $30 \mathrm{KV}$, FEI company, Netherlands) was applied in comparison to the positive biofilms. The experiment was estimated using glass slices $(1 \times 1 \mathrm{~cm})$ and at the end of the incubation period, the slices were washed twice with $\mathrm{pH}$ 7.4 PBS for $5 \mathrm{~min}$ each. The slices were fixed with $4 \%$ glutaraldehyde for 15 min and washed twice with PBS. Afterward, the slices were dehydrated using different concentrations of ethanol $(25,50,75$ and $100 \%) 15$ min each and at the end stored in a desiccator.

\section{RESULTS AND DISCUSSION:}

Recently the authors have been focusing on palladium-catalysed cross-coupling methodology that formed the impetus to examine 2-chloro3 -quinolinecarboxaldehyde 6 as a possible substrate for annulation onto acetylene using a standard method via one-pot reaction conditions in order to produce acridin2-yl(phenyl)methanone (9) in good yields, as outlined in fig. $2^{[38-41]}$. This study has been energized by the achievement of the intramolecular reaction of an $\alpha, \beta$ unsaturated ketone, a group that normally inert to organo-
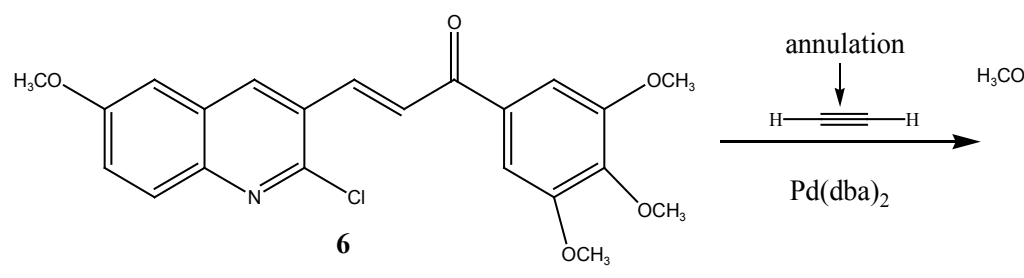

Fig. 2: Annulation reaction scheme

Annulation of internal acetylene with 3-(2-chloro-6-substitutedquinolin-3-yl)-1-(3,4,5-tri substitutedphenyl)prop-2-en-1-one (6) to produce (7-substitutedacridin-2-yl)(3,4,5-trisubstitutedphenyl) methanone (9) 
palladium species, as it has been previously reported ${ }^{[42]}$. Therefore, these compounds have attracted scientific attention in organic synthesis thus to study the reaction of cis- and trans-3-(2-chloro-6-substitutedquinolin3-yl)-1-(3,4,5-trisubstitutedphenyl)prop-2-en-1-one palladium complexes (7) and (8) with acetylene through an oxidative addition reaction. This interest was mainly attributed to 2 reasons, firstly such reactions have not been noted and secondly, related to their distinct behavior in comparison to their analogous complexes that were having vinylquinoline palladium complexes. Thus, more stable insertion products were expected due to their greater aqueous characters. These reactions were taken place at room temperature with mild conditions appropriate with a lot of functional groups, providing high yields of cyclic homoallylic ketones, including heterocyclic derivatives. The reaction of acetophenone derivative (5) with chloro-quinoline (4) afforded 3-(6-methoxy-2-chloroquinolin-3-yl)1-(3,4,5-trimethoxyphenyl)prop-2-en-1-one (6). The reaction of those prepared quinoline derivative using oxidative addition reaction with $\mathrm{Pd}(\mathrm{dba})_{2}$ and the monodentate triphenyl arsine was afforded the corresponding trans-quinoline-palladium complexes (7). Insertion reaction of $\mathrm{Pd}(\mathrm{II})$ by a reaction of (6) with $\operatorname{Pd}(\mathrm{dba})_{2}$, in the presence of triphenyl arsine in acetone at room temperature, afforded trans-palladium complexes (7) with derivatives in position-3, which was reacted with acetylene to give vinyl palladium complexes. This reaction was cyclized using depalladation reaction in an aqueous medium to afford the desired compounds as outlined in fig. 2 converted into acridin-2-yl(aryl) methanone (9) in around $65 \%$ yield and confirmed by IR, ${ }^{1} \mathrm{H}-\mathrm{NMR}(300 \mathrm{MHz})$ and GC/MS. Similarly, the development of the previous method for the synthesis of (9) via reaction of cis-palladium complexes (8) with acetylene to give vinyl palladium complexes that cyclized and undergo depalladation in an aqueous medium finally afforded the same products as outlined in fig. 3. By comparing cis- and trans-palladium complexes in their capability towards insertion reactions, it was observed that the trans-palladium complexes were reacted with acetylene with a greater yield than their corresponding cis-palladium complexes. This finding was attributed to the steric hindrance that present in cis-complexes, which further reduces the acetylene moiety to attack palladium carbon bond and further leading to smaller product yield. The application of an aqueous medium in palladium-catalysed reactions has attracted attention. This may be attributed mainly to it is the water-based synthetic process, is inherently safer and considered as inexpensive. Furthermore, this reaction was not required dry solvents and the end products may simply be separated by extraction and in the end, it greatly expedites the whole operation. Therefore, the application of water in palladium-catalysed reactions describes the highest economically and environmentally viable options for several organic transformations.

The antibacterial activity of the intermediate compounds $(7,8)$ in comparison to the final product compound (9) were evaluated using the agar well diffusion method. Results reported in Table 1 showed broad antibacterial spectrum represented by inhibition zones of the reaction-products ranging from 32$21 \mathrm{~mm}$. The intermediate trans-palladium complex compound (7) showed greater antibacterial activity in comparison to the intermediate cis-palladium complex compound (8) as it has been previously reported (fig. 4) ${ }^{[43,44]}$. The final product (9) displayed very low

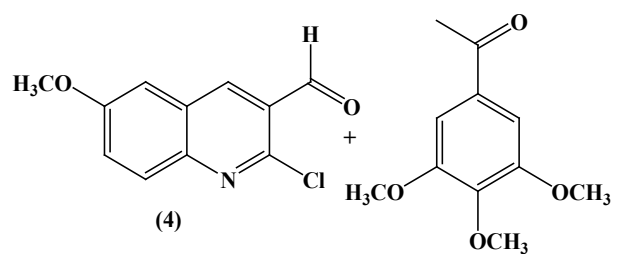

(5)

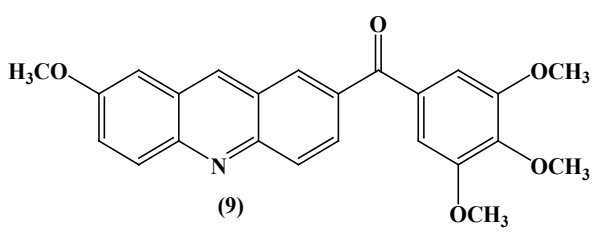

(9)

Fig. 3: Synthetic scheme of trans-aryl palladium(II) intermediates

The trans-aryl palladium (II) intermediates (7) in these annulations are usually generated by oxidative addition of aryl halide (6) to a Pd (0) catalyst

Special Issue 3, 2020

Indian Journal of Pharmaceutical Sciences

87 
www.ijpsonline.com

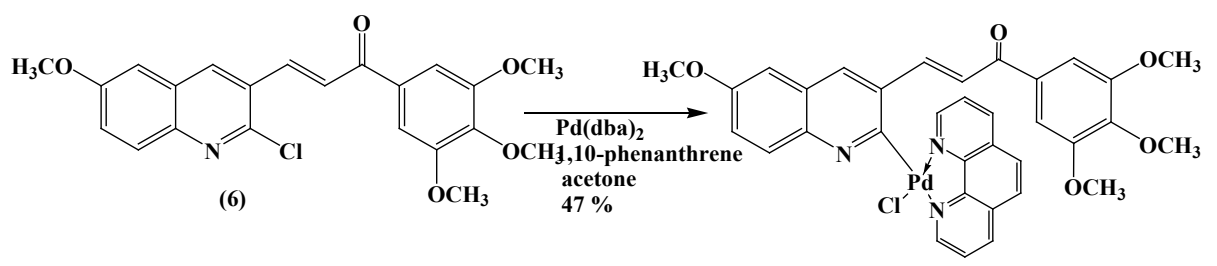

(8)

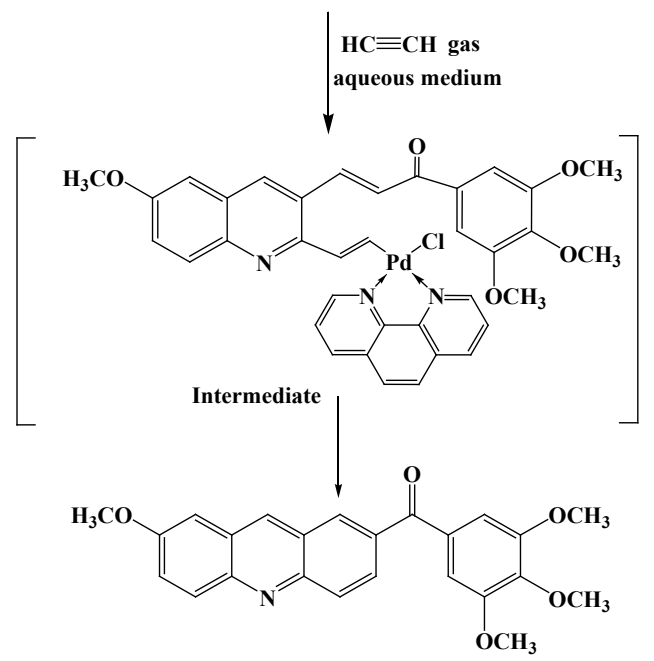

(9)

Fig. 4: Synthetic scheme of cis-aryl palladium(II) intermediates and the final product

The cis-aryl palladium(II) intermediates (8) in these annulations are usually generated by oxidative addition of aryl halide (6) to a Pd (0) catalyst

TABLE 1: ANTIBACTERIAL ACTIVITY OF PALLADIUM COMPLEX INTERMEDIATES

\begin{tabular}{lcccc}
\hline Samples & $\begin{array}{c}\text { Staphylococcus aureus } \\
\text { (DSM 3463) }\end{array}$ & $\begin{array}{c}\text { Bacillus subtilis } \\
\text { (ATCC 6633) }\end{array}$ & $\begin{array}{c}\text { Escherichia coli } \\
\text { (ATCC 8739) }\end{array}$ & $\begin{array}{c}\text { Pseudomonas aeruginosa } \\
\text { (ATCC 9027) }\end{array}$ \\
\hline 7 & 32 & 26 & 25 & 23 \\
8 & 30 & 25 & 25 & 22 \\
9 & 28 & 23 & 22 & 21 \\
TE $(30 \mu \mathrm{g})$ & 24 & 23 & - & - \\
NA $(30 \mu \mathrm{g})$ & - & - & 20 & - \\
\hline
\end{tabular}

Antibacterial activity of 7. trans-palladium complex intermediate, 8. cis-palladium complex intermediate in comparison to 9 . the final reaction product. Numbers are the mean of the inhibition zone diameter $(\mathrm{mm})$. TE is tetracycline and NA is nalidixic acid.

activity, which was attributed mainly to the absence of palladium. Moreover, all the compounds have exhibited better activity towards Gram-positive bacteria (32 $-26 \mathrm{~mm}$ ) than the Gram-negative bacteria (25-21 mm). This result could be attributed to the cell membrane characteristics, in Gram-positive bacteria, it is a single bilayer that is very sensitive to antibacterial agents. While the cell membrane in Gram-negative bacteria is a bilayer more resistant to antibacterial agents. Moreover, the stability of the bacterial cell membrane disruption has relied on two factors, the number of terminal charged groups and (ii) the bio-permeability which related to size and molecular weight and/ or lipophilic groups ${ }^{[45,46]}$. The results in Table 2 displayed the MICs and the MBCs of trans- and cispalladium complex compounds $(7,8)$ in comparison to the final product (9). The trans-palladium complex intermediate (7) showed lower MICs and MBCs for the Gram-positive bacteria (130.3 and 156-312.5 ppm) than for the Gram-negative bacteria (312.5 and 312.5 $-520.8 \mathrm{ppm})$, respectively. While the cis-palladium complex intermediate (8) MICs and MBCs for the Gram-positive bacteria (156.4 and 208.4-312.5 ppm) were lower than those for Gram-negative bacteria (312.5-416.6 and $625 \mathrm{ppm})$. Furthermore, the final compound (9) demonstrated MICs and MBCs for the Gram-positive bacteria (156.4-312.5 and 208.4 $-312.5 \mathrm{ppm}$ ) were lower than Gram-negative bacteria (416.6 and $625 \mathrm{ppm}$ ). The results that reported that the lowest MIC/MBC were attributed to the trans-palladium complex intermediate $(7)^{[47]}$. The hypothesized antibacterial mechanism of the palladium complex 
compounds may relate to their metabolic pathway inhibitory action, which alters the DNA replication (the complexes carry metal to the target DNA). Furthermore, these compounds also have the strength of hydrogen bonding to the cell wall ${ }^{[48]}$.

Bacterial biofilm, which considered as an example of physiological modifications of bacteria that are displaying high resistance to different antibacterial agents ${ }^{[49,50]}$. This bacterial resistance may be interpreted by different mechanisms, not necessarily related to ones. The first mechanism may be attributed to the extracellular polymeric substances (EPS) produced from bacterial biofilms that prevent antimicrobial agent penetration. The second mechanism is related to the embedded bacterial biofilm that is in fact, not actively engaged in cell division and is smaller in size; thus, these are less permeable to antimicrobial agents. The third mechanism is the antibiotic degrading enzyme ( $\beta$-lactamase) produced by many bacterial species, which can inhibit the activity of the $\beta$-lactam ring of many antibiotics as penicillin and cephalosporins. Furthermore, $\beta$-lactamases can be immobilized and highly accumulated in the EPS that strongly inactivate the action of antimicrobial agents ${ }^{[51]}$. It has been reported that there is a great concern in inhibiting and/or eradicating the bacterial biofilms on different surfaces. Therefore, one of the aims of this work was directed to study the novel application of the trans and cis-palladium complex intermediates $(7,8)$ in comparison to the final reaction product (9) as antibacterial biofilms against the

\section{TABLE 2: THE MINIMUM INHIBITORY CONCENTRATIONS (MIC) AND THE MINIMUM BACTERICIDAL CONCENTRATIONS (MBC) OF PALLADIUM COMPLEX INTERMEDIATES}

\begin{tabular}{|c|c|c|c|c|c|c|c|c|}
\hline \multirow[t]{2}{*}{ Samples } & \multicolumn{2}{|c|}{$\begin{array}{c}\text { Staphylococcus aureus } \\
\text { (DSM 3463) }\end{array}$} & \multicolumn{2}{|c|}{$\begin{array}{c}\text { Bacillus subtilis (ATCC } \\
6633 \text { ) }\end{array}$} & \multicolumn{2}{|c|}{$\begin{array}{l}\text { Escherichia coli } \\
\text { (ATCC } 8739 \text { ) }\end{array}$} & \multicolumn{2}{|c|}{$\begin{array}{c}\text { Pseudomonas aeruginosa } \\
\text { (ATCC 9027) }\end{array}$} \\
\hline & MIC & $M B C$ & MIC & $M B C$ & MIC & $M B C$ & MIC & $M B C$ \\
\hline & (PPM) & (PPM) & (PPM) & (PPM) & (PPM) & (PPM) & (PPM) & \\
\hline 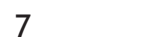 & $130.3 \pm 36.9$ & $156.4 \pm 0.0$ & $130.3 \pm 36.9$ & $312.5 \pm 0.0$ & $312.5 \pm 0.0$ & $312.5 \pm 0.0$ & $312.5 \pm 0.0$ & $520.8 \pm 147.3$ \\
\hline & $156.0 \pm 0.0$ & $208.4 \pm 73.6$ & $156.4 \pm 0.0$ & $312.5 \pm 0.0$ & $312.5 \pm 0.0$ & $625 \pm 0.0$ & $416.6 \pm 147.3$ & $625 \pm 0.0$ \\
\hline 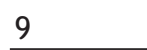 & $156.4 \pm 0.0$ & $208.4 \pm 73.6$ & $312.5 \pm 0.0$ & $312.5 \pm 0.0$ & $416.6 \pm 147.3$ & $625 \pm 0.0$ & $416.6 \pm 147.3$ & $625 \pm 0.0$ \\
\hline
\end{tabular}

The minimum inhibitory concentrations (MIC) and the minimum bactericidal concentrations (MBC) of 7. trans-palladium complex intermediate and 8. cis-palladium-complex intermediate in comparison to 9. the final reaction product against different standard bacterial strains. The results expressed as mean of the samples concentrations (ppm) with standard deviations (SD).

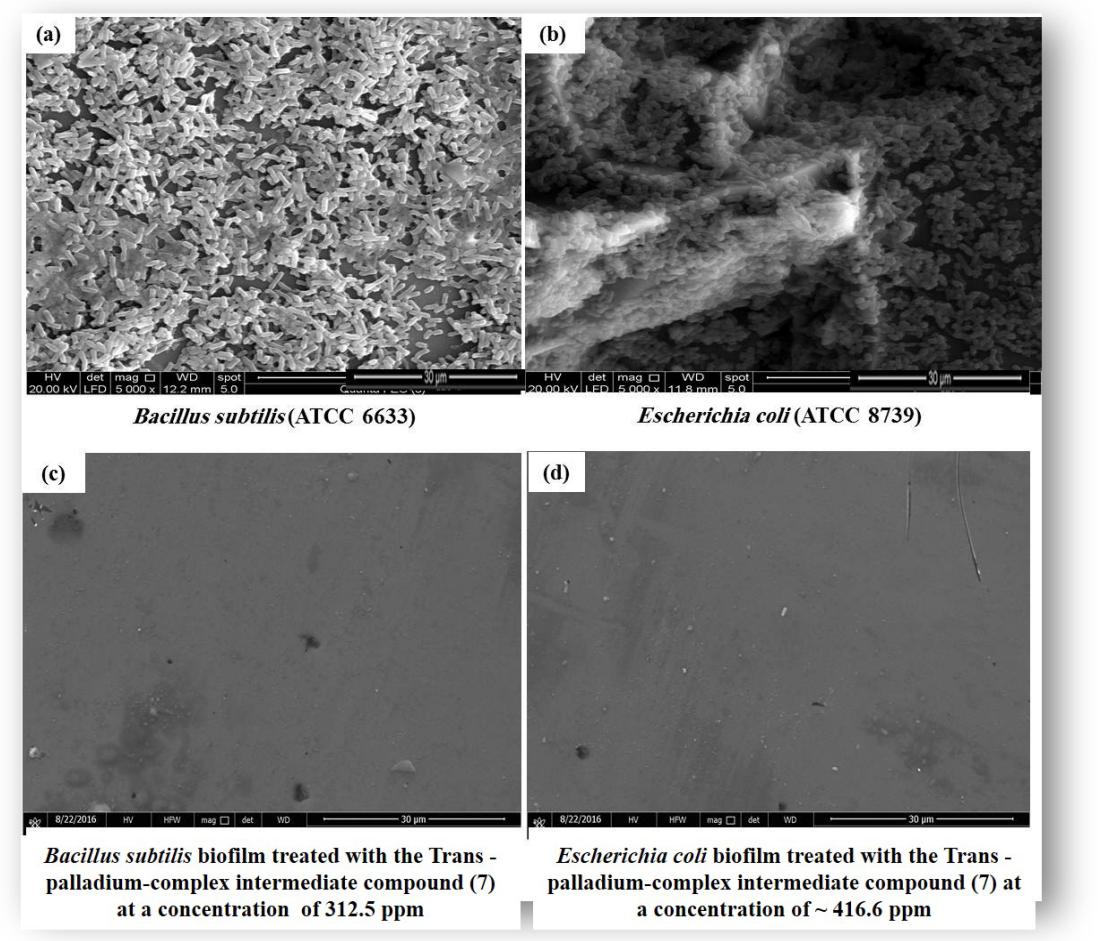

Fig. 5: SEM pictomicrographs of the bacterial biofilms on glass surfaces

SEM images of the bacterial biofilms (a) Bacillus subtilis (ATCC 6633) biofilm, (b) Escherichia coli (ATCC 8739) biofilm, (c) Bacillus subtilis biofilm treated with trans-palladium-complex intermediate (7) at a concentration of 312.5 ppm and (d) Escherichia coli biofilm treated with trans-palladium-complex intermediate (7) at a concentration of $416.6 \mathrm{ppm}$ 
bacterial strains that induced positive biofilms Bacillus subtilis and Escherichia coli (fig. 5a and 5b). The trans and cis-palladium-complex intermediates $(7,8)$ and final reaction product (9), have displayed antibiofilms activity against the positive-induced bacterial biofilms with MIBCs of 312.5-625 ppm (fig. 6 and Table 3). The trans-palladium-complex intermediate compound (7) exhibited better antibiofilm activity against the B. subtilis and E. coli at MIBCs 312.5 and $416.6 \mathrm{ppm}$, respectively in comparison to the cis-palladium-complex intermediate compound (8) with MIBCs 312.5 and $625 \mathrm{ppm}$ (Table 3 ). The palladium-complex intermediates $(7,8)$ have demonstrated better antibacterial biofilms activity in comparison to the final reaction product (9) that was mainly attributed to the effect of the nonpalliated compound on the bacterial cells in planktonic and biofilms forms. One of the initial hypotheses of the action of novel synthesized palladium compounds on biofilm inhibition is their high binding ability to intracellular DNA. Such binding has been displayed as an important factor in the extracellular biofilm`s matrix which further leads to rapid disruption ${ }^{[52,53]}$.

In summary, alternative access to cyclopenta[b] quinolin-1-one derivatives (7) has been developed. The major by-product of these reactions was dibenzal acetone associated with $\operatorname{Pd}(\mathrm{dba})_{2}$ and accordingly, this applied method does not need the initial synthesis of a requisite (poly) organometallic compound. Hence, it will reduce the reaction steps. Therefore, this synthesis process has displayed economic and environmental visibility to cyclopenta[b]quinolin1-one derivatives. The carbon-oxygen double bond of heteroaryl carboxaldehyde has been reported to take part in the organo-palladium annulation reaction. The process reaction was appropriated with many functional groups and afforded products in high yields. Furthermore, the synthesized intermediate products have shown a great activity than non-palliated compounds. The synthesized trans and cis-palladiumcomplex intermediate compounds $(7,8)$ in comparison to the final reaction product (9) have been successfully

\begin{tabular}{lcc} 
TABLE 3: THE MINIMUM BIOFILM & INHIBITORY \\
CONCENTRATIONS (MBIC) & OF & PALLADIUM \\
COMPLEX INTERMEDIATES & \\
\hline Samples & $\begin{array}{c}\text { Bacillus subtilis } \\
\text { (ATCC 6633) }\end{array}$ & $\begin{array}{c}\text { Escherichia coli } \\
\text { (ATCC 8739) }\end{array}$ \\
\hline 7 & $312.5 \pm 0.0$ & $416.6 \pm 147.3$ \\
8 & $312.5 \pm 0.0$ & $625.0 \pm 0.0$ \\
9 & $625.0 \pm 0.0$ & $625.0 \pm 0.0$ \\
\hline
\end{tabular}

The minimum biofilm inhibitory concentrations (MBIC) of 7. transpalladium complex intermediate and 8 . cis-palladium complex intermediate in comparison to 9 . the final reaction product against different standard bacterial biofilms. The result expressed as the mean samples concentrations in ppm) and standard deviations (SD).

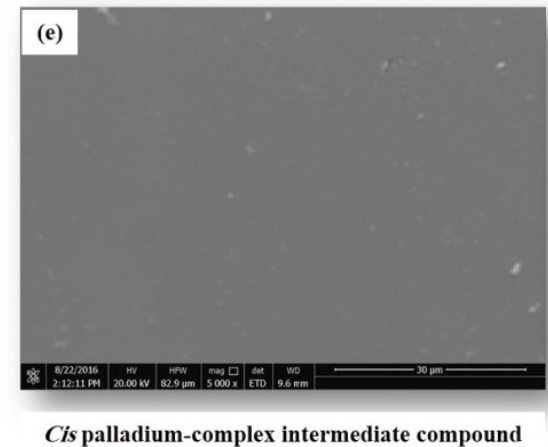

(8) with Bacillus subtilis

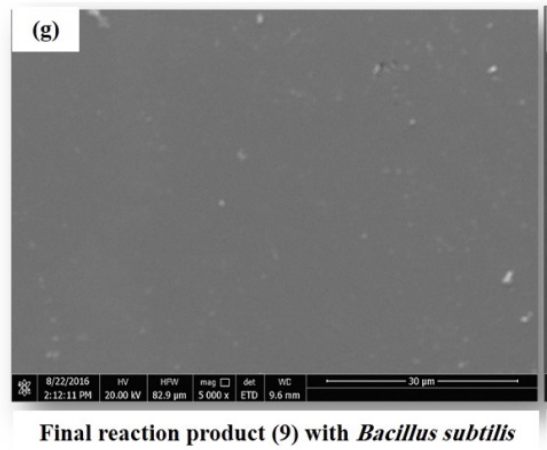

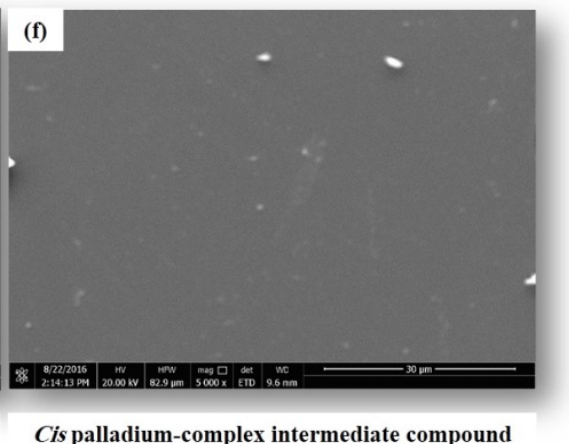

Cis palladium-complex intermediate compound (8) with Escherichia coli

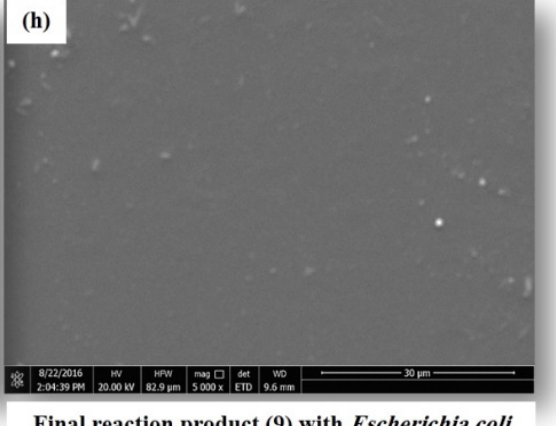

(h)

Fig. 6: SEM pictomicrographs of the bacterial biofilms on glass surfaces contd

SEM images of the bacterial biofilms (e) Bacillus subtilis biofilm treated with the cis-palladium-complex intermediate compound (8) at a concentration of $312.5 \mathrm{ppm}$ and (f) Escherichia coli biofilm treated cis-palladium complex intermediate (8) at a concentration of $625 \mathrm{ppm}$, (g) Bacillus subtilis biofilm treated with the final reaction product (9) at a concentration of $625 \mathrm{ppm}$, and (d) Escherichia coli biofilm treated with the final reaction product (9) at a concentration of $625 \mathrm{ppm}$. 
applied as antibacterial agents. The trans-palladium complex intermediate (7) displayed better antibacterial activity with low minimum inhibitory concentration/ minimum bactericidal concentration in comparison to the cis-palladium complex intermediate (8) and the final reaction product (9). Furthermore, the synthesized trans and cis-palladium complex intermediates $(7,8)$ in comparison to the final reaction product (9) have been successfully applied as antibacterial biofilms against standard bacterial strains that induced positive biofilms. In addition, the trans-palladium-complex intermediate (7) has displayed greater antibacterial biofilms activity at very low minimum biofilm inhibitory concentration.

\section{Acknowledgments}

Authors acknowledge financial support from the Egyptian Chemical Society for their partial support of this research, and Faculty of Science, Ain Shams University for Solvents and Fine Chemicals Co., Ltd. for donating the palladium chloride and triphenyl arsine.

\section{Informed consent:}

Informed consent was obtained from all individual participants included in the study.

\section{Conflict of interest:}

All authors report no conflicts of interest in this work..

\section{REFERENCES}

1. Vicente J, Saura-Llamas I, Jones PG. Orthometallated primary amines. Facile preparation of the first optically active cyclopalladated primary amines. J ChemSoc Dalton Transact. 1993;23:3619-24.

2. Thompson JM, Heck RF. Carbonylation reactions of orthopalladation products of. alpha-arylnitrogen derivatives. J Organic Chem 1975;40:2667-74.

3. Ryabov AD, Sakodinskaya IK, Yatsimirsky AK. Comparative study of the mechanism of alkynelation of orthopalladatedbenzylamines and acetanilides. J Organomet Chem. 1991;406:309-21.

4. O'Sullivan RD, Parkins AW. The synthesis of N-heterocycles using ortho-metallated primary benzylamine complexes of palladium (II) and platinum (II). J ChemSocChemCommun 1984:1165-6.

5. Pfeffer M. Reactions of cyclopalladated compounds and alkynes: New pathways for organic synthesis. Compendium Chem Works 1990;109:567-76.

6. López C, Solans X, Tramuns D. Formation of an endo-type nine-membered metallocycle via insertion of diphenylacetylene into the $\sigma$ (Pd-Csp2, ferrocene) bond. X-Ray crystal structure of $\left[\mathrm{Pd}\left\{\left\{\left(\mathrm{C} 6 \mathrm{H} 5 . \mathrm{C} . \mathrm{C} . \mathrm{C}_{6} \mathrm{H}_{5}\right) 2\left(\eta 5-\mathrm{C} 5 \mathrm{H}_{3}\right) \mathrm{CH} . \mathrm{N} . \mathrm{CH}_{2} \cdot \mathrm{C}_{6} \mathrm{H}_{5}\right\}-\mathrm{Fe}\right.\right.$ $\left.\left.\left(\eta 5-\mathrm{C}_{5} \mathrm{H}_{5}\right)\right\} \mathrm{Cl}\right] \cdot \mathrm{CH}_{2} \mathrm{Cl}_{2}$. [J Organomet Chem. 1994;471:26572.

7. Maassarani F, Pfeffer M, Spencer J, Wehman E. Selective hetero-and carbo-cycle syntheses via masked cyclopalladated secondary amine and ketone functions. J OrganometChem 1994;466:265-71.

8. Heck RF, Palladium Reagents in Organic Syntheses. Academic Press. New York. 1985.

9. Wu G, Rheingold AL, Geib SJ, Heck RF. Palladium-catalyzed annulation of aryl iodides with diphenylacetylene. Organomet 1987;6:1941-6.

10. Vicente J, Abad JA, Stiakaki MA, Jones PG. Palladiumassisted rearrangement of $\mathrm{HC}(\mathrm{O}) \mathrm{C}_{6} \mathrm{H}_{2}(\mathrm{OMe}) 3-3,4,5$ to $\mathrm{HC}(\mathrm{O})$ $\mathrm{C}_{6} \mathrm{H}_{2}(\mathrm{OMe})$ 3-2,3,4. J ChemSocChemCommun 1991;3:137-9.

11. Katritzky AR, Rachwal S, Rachwal B. Recent progress in the synthesis of $1,2,3,4$,-tetrahydroquinolines. Tetrahed 1996;52:15031-70.

12. Magomedov NA. Efficient Construction of Cyclopenta[b] quinoline Core of Isoschizozygane Alkaloids via Intramolecular Formal Hetero-Diels-Alder Reaction. Organic Let 2003;5:2509-12.

13. Molander GA. Diverse methods for medium ring synthesis. AccChem Res 1998;31:603-9.

14. De Frutos O, Curran DP. Solution Phase Synthesis of Libraries of Polycyclic Natural Products. J Comb Chem 2000;1:639-49.

15. Tietze LF. Domino Reactions in Organic Synthesis. Chem Rev 1996;1:115-36.

16. Soderberg BC, Comprehensive Organometallic Chemistry II. $7^{\text {th }}$ ed. Pergamon Oxford. 1995.

17. Backvall JE. Organo-Metallic Transformations. Pure ApplChem 1992;64:429-39.

18. Wilson I, Jackson RF. Palladium (0) catalysed and copper (I) promoted reactions of the secondary zinc reagent derived from L-threonine. J ChemSoc Perkin Transact 2002;24:2845-50.

19. Roesch KR, Larock RC. Synthesis of isoindolo[2, 1-a] indoles by the palladium-catalyzed annulation of internal acetylenes. $\mathrm{J}$ Organ Chem 2001;66:412-20.

20. Tusek-Bozic L, Matijasic I, Bocelli G, Calestani G, Furlani A, Scarcia V, et al. Preparation, characterization and activity of palladium (II) halide complexes with diethyl 2-quinolylmethylphosphonate (2-dqmp). X-Ray crystal structures of trans-[Pd (2-dqmp) 2 X 2$](\mathrm{X}=\mathrm{Cl}$ or $\mathrm{Br})$. J ChemSocChemCommun Dalton Transact 1991;2:195-201.

21. Lee HJ, Lee SH, Kim HC, Lee YE, Park S. Pseudohalide complexes of palladium(II) containing PCP pincer: Synthesis, characterization, and their antimicrobial activities. OrganometChem2012;717:164-71.

22. Bugarcic ZM, Divac VM, Kostic MD, Jankovic NZ, Heinemann FW, Radulovic NS, et al. Synthesis, crystal and solution structures and antimicrobial screening of palladium (II) complexes with 2-(phenylselanylmethyl) oxolane and 2-(phenylselanylmethyl) oxane as ligands. J InorgBiochem 2015;143:9-19.

23. Lippard SJ, Berg JM. Principles of bioinorganic chemistry. Mill Valley. 1994.

24. GiovagniniL, MarzanoC, BettioF, Fregona D. Mixed complexes of $\mathrm{Pt}$ (II) and $\mathrm{Pd}$ (II) with ethylsarcosinedithiocarbamate and 2-/3-picoline as antitumor agents. J InorgBiochem 2005;99:2139-50.

25. Stoodley P, Sauer K, Davies DG, Costerton JW. Biofilms as complex differentiated communities. Annual Rev Microbiol 2002;56:187-209.

26. Bayoudh S, Othmane A, Mora L, Ouada HB. Assessing bacterial adhesion using DLVO and XDLVO theories and the jet impingement technique.Colloids Surf B Biointerfaces 2009;73:1-9. 
27. Simoes M, Simoes LC, Cleto S, Pereira MO, Vieira MJ. The effects of a biocide and a surfactant on the detachment of Pseudomonas fluorescens from glass surfaces. Int J Food Microbiol2008;121:335-41.

28. Hamadelgazwy ASS. Conversion of iminoacylquinolinylpalladium (II) complexes into novel oxopyrrolo[3,4-b] quinolines via depalladation reactions. App OrganmetChem 2009;23:32-4.

29. Perez C. Antibiotic assay by agar-well diffusion method. ActaBiol Med Exp 1990;15:113-5.

30. Wiegand I, Hilpert K, Hancock RE. Agar and broth dilution methods to determine the minimal inhibitory concentration (MIC) of antimicrobial substances. Nat Protocol 2008 Feb;3:163.

31. Mims CA, Playfair JHL, Roitt IM, Wakelin D,Williams R. Antimicrobials and chemotherapy. In: Mims CA, editor. Medical Microbiology Review. UK: Mosby Europe 1993;1-34.

32. Amsterdam D, Susceptibility testing of antimicrobials in liquid media. In: Antibiotics in laboratory medicine, Loman V. 4th ed. Williams and Wilkins, Baltimore. 1996;52-111.

33. Labena, A., Hegazy, M. A., Kamel, W. M., Elkelish A., Hozzein W.N. Enhancement of A Cationic Surfactant by Capping Nanoparticles: Synthesis, Characterization and Multiple Applications. Molec. 2020; 25: 1-19.

34. Labena A, Kabel KI, Farag RK. One-pot synthesize of dendritic hyperbranched PAMAM and assessment as a broad spectrum antimicrobial agent and anti-biofilm. Mat SciEng 2016;58:1150-9.

35. Clinical Laboratory Standards Institute (CLSI), Reference Method for Broth Dilution Antifungal Susceptibility Testing of Yeasts. Approved Standard M27-A2. National Committee for Clinical Laboratory Standards, Wayne, PA. USA, 2002.

36. Rukayadi Y, Han S, Yong D, Hwang JK.In Vitro Antibacterial Activity of Panduratin A against Enterococci Clinical Isolates. Biol Pharm Bulletin 2010;33:1489-93.

37. Stepanovic S, Vukovic D, Dakic I, Savic B, Svabic-Vlahovic M, J Microbiol Meth 2000;40:175-9.

38. Yarwood JM, Bartels DJ, Volper EM, Greenberg EP, J Bact 2004;186:1838-50.

39. S. Sarkar and M. M. Pires. d-Amino Acids Do Not Inhibit Biofilm Formation in Staphylococcus aureus. PLoS One 2015;10:117613.

40. T. Su, X. Han, X. Lu. Palladium(II)-catalyzed oxidative annulation of alkenylindoles with alkynes initiated by $\mathrm{C}-\mathrm{H}$ activation. Tetrahedron Lett2014;55:27-30.

41. Elgazwy ASSH, Nassar SM, Ismail NSM, Atta-Allah SR, Sarg MT, Soliman DH, ElgamasyMA. Curr Med Chem 2012;19:3967-81.

42. Elgazwy ASSH. Improved Studies of Cross-Coupling Reactions of 5-(tri-n-butystannyl)-and 5,5'-bis(tri-nbutylstannyl)-2,2'-Bithiophene with Aryl halides. J Hetero Chem 2004;41:755-9.
43. Elgazwy ASSH. 2,2'-Bithiophene-5,5'-Tetrahydroisoquinoline as MichellamineAnalogs J SulfurChem2004;25:275-82.

44. Larock RC, Doty MJ, Cacchi S. Synthesis of indenones via palladium-catalyzed annulation of internal alkynes. J Org Chem1993;58:4579-83.

45. Navarro M, Lehmann T, Cisneros-Fajardo EJ, Fuentes A, Sanchez-Delgado RA, Silva P, et al. Toward a novel metalbased chemotherapy against tropical diseases.: Part 5. Synthesis and characterization of new $\mathrm{Ru}$ (II) and $\mathrm{Ru}$ (III) clotrimazole and ketoconazole complexes and evaluation of their activity against Trypanosomacruzi. Polyhed 2000;19:2319-25.

46. Caires AC. Recent advances involving palladium (II) complexes for the cancer therapy. Anti-Cancer Agent ME. 2007;7:484-91.

47. Rasines B, Hernandez-Ros JM, de las Cuevas N, Copa-Patino JL, Soliveri J, Munoz-Fernandez MA, et al. Water-stable ammonium-terminated carbosilanedendrimers as efficient antibacterial agents. Dalt Transact 2009;40:8704-13.

48. Kenawy ER, Worley SD, Broughton R. The chemistry and applications of antimicrobial polymers: a state-of-the-art review. Biomacromol 2007;8:1359-84.

49. Abu-Surrah AS, Al-Sa'doni HH, Abdalla MY. Palladiumbased chemotherapeutic agents: routes toward complexes with good antitumor activity. Cancer Ther 2008;6:1-10.

50. Tirmizi SA, Nadeem S, Hameed A, Wattoo MH, Anwar A, Ansari ZA, et al. Synthesis, spectral characterization and antibacterial studies of palladium (II) complexes of heterocyclic thiones. J Spectros 2009;23:299-306.

51. M. Hentzer, and M. Givskov. Pharmacological Inhibition of Quorum Sensing for the Treatment of Chronic Bacterial Infections. J ClinInves 2007;112:1300-7.

52. Rajasekaran R, Gebrekidan Y. A review on antibacterial phytochemical constitutions present in Aervalanata and their mode of action against bacterial biofilm. Int J Pharm Bioll Arch 2018;9:16-30.

53. Trentin DS, Giordani RB, Zimmer KR, Silva AG, Silva MS, Correia MTS, et al. Potential of medicinal plants from the Brazilian semi-arid region against Staphylococcus epidermidis planktonic and biofilm lifestyles anielle J Ethno Pharm 2011;137:327-335.

54. Rice KC, Mann EE, Endres JL, Weiss EC, Cassat JE, Smeltzer MS, et al. The cidAmurein hydrolase regulator contributes to DNA release and biofilm development in Staphylococcus aureus. Proceed Nat Academy Sci 2007;104:8113-8.

This is an open access article distributed under the terms of the Creative Commons Attribution-NonCommercial-ShareAlike 3.0 License, which allows others to remix, tweak, and build upon the work non-commercially, as long as the author is credited and the new creations are licensed under the identical terms

This article was originally published in a special issue, "Biomedical applications in Pharmaceutical Sciences" Indian J Pharm Sci 2020:82(2)Spl issue3;83-92 